\title{
Exploring key service quality dimensions at a winery from an emerging market's perspective
}

\author{
Kyuho Lee, kyuho.lee@sonoma.edu \\ Melih Madanoglu, mmadanog@fau.edu \\ Jae-Youn Ko, jyko@khu.ac.k
}

\begin{abstract}
Food and alcoholic consumption is influenced by cultural and family roots deeply embedded in a person's life (Gorefield, 2015), which makes it less likely that consumers will change their eating and drinking habits. Yet, wine consumption has emerged as one of the fastest growing alcoholic beverages in China. Chinese wine consumption already ranks fifth globally and increased at an annual rate of $25 \%$ between 2007 and 2011 (Wine Intelligence, 2013).

Continuing economic growth and a growing urban and higher class population have spurred wine consumption in China (Liu \& Murphy, 2007). For example, the Chinese upper class will reach 91 million people by 2020 (Wine Intelligence, 2013). Having more higher-class Chinese consumers has implications for wine sales because these consumers view drinking wine as consuming a Western lifestyle, which has been considered a better and positive lifestyle (Yu et al., 2009). Also, wine may serve as a medium for Chinese consumers to express their social status, signal their wealth, and feel cosmopolitan, which might be quite different from the motivations of Western consumers (Wine Intelligence, 2013). Along with the high popularity of Western luxury brands, such as Prada and Louis Vuitton, drinking wine has become a key element in being cosmopolitan among emerging middle and higher class Chinese consumers (Fan, 2007).

Developments in the wine consumption arena have led to the emergence of wine tourism as a leisure activity among Chinese consumers (Qiu et al., 2013). More and more Chinese wine tourists are visiting domestic and international wineries (Qiu et al., 2013). For instance, the Chinese wine tourism market is the second largest international market for Australian wineries behind British visitors (Edgar, 2014). Furthermore, more than 60,000 Chinese wine tourists visited Napa Valley, California in 2014 which accounts for 14\% of international tourists in Napa Valley region (Quackenbush, 2015)
\end{abstract}

Given the increasing prominence of Chinese winery tourists, there exist a need to explore which service quality attributes influence Chinese wine tourists' satisfaction 
and loyalty to different wineries. Prior literature contends that Asian consumers' evaluation of service quality dimensions differ from that of Western consumers considerably on the basis of culture (de Mooij, 1998). Stauss and Mang (1999) claim that Asian consumers tend to have higher service expectations compared to that of Western consumers.

In a similar vein, Chinese wine tourists might have a different perspective on wine tourism compared to Western consumers from Italy, Spain or Australia where wine is a part of everyday life and visiting a winery is nothing special for Italian and Spanish consumers (Charters \& Ali-Knight, 2002). The concept of wine drinking and wine tourism is a relatively new activity among Chinese consumers (Yu et al., 2009). Given the fact that wine sales account for merely five percent of total alcoholic beverage sales in China in 2014, the majority of Chinese wine consumers do not possess extensive wine knowledge (Swindell, 2015). Yang and Paladino (2015) suggest that underlying motivations for wine consumption among Chinese consumers is strongly associated strongly with social status and social approval. Drinking wine may illuminate a person's high social status and prestige in Chinese society because wine is a metaphor of desired Western lifestyle (Yang \& Paldino, 2015). Thus, country of origin effect in wine consumption among Chinese wine consumers is important (Yang 7 Paldino, 2015). Chinese wine consumers view wine produced in traditional Western wine countries such as France and Germany more positively than wine produced in non-Western countries (Yang \& Pladino, 2015). These factors should influence Chinese wine tourists' expectations when they visit a winery.

While a substantial body of literature exists on wine tourism, to date Chinese wine tourists have not received much academic attention. This is because, overall, wine tourism research is in its infancy stage (Charters \& Ali-Knight, 2002). As a consequence, researchers have not explored wine tourism among Chinese consumers in spite of the importance of this topic. Most extant wine tourism research has been developed on the basis of Western wine tourists' perspectives using Australian (Charters \& Ali-Knight, 2002; Sparks, 2007), New Zealander (Mitchell \& Hall, 2004), European (Marzo-Navarro \& Pedraja-Iglesias, 2009), South African (Bruwer, 2003), Chilean (Hojman \& Hunter-Jones, 2012) and North American (Brown \& Getz, 2005) samples of wine tourists. The application of the existing wine tourism research to Chinese wine tourists might be challenging because Chinese wine tourists may have different preferences and values, or look for different winery features compared to Western wine tourists during their winery visits.

Generally, Chinese wine consumers may not possess extensive wine knowledge and may have different motivations compared to their Western counterparts since there are still many novice wine drinkers in China who drink wine only on special occasions (Qiu et al., 2013; Wine Intelligence, 2013). There has been little effort to identify the attributes or factors that are associated with Chinese wine tourists. Given the intricacy of understanding wine tourism, which encompasses tangible products such as wine products and intangible products such as service quality and service 
atmosphere, not knowing which service attributes influence satisfaction with wineries is a substantial gap.

To close this gap, the present study aims to answer the following question:

- What are the important service quality dimensions and winery feature that influence Chinese wine tourists' satisfaction and loyalty when visiting a winery?

The results of the study should contribute to the existing body of wine tourism literature and help scholars and winery operators better understand Chinese consumers' attitudes toward wine tourism and winery visits. The results of this study will provide Western winery operators who aim to attract Chinese wine tourists with useful operational strategies.

\section{References}

Brown, G. and Getz, D. (2005) Linking wine preferences to the choice of wine tourism destinations. Journal of Travel Research. 43 (February). p. 266-276.

Bruwer, J. (2004) South African wine routes: some perspectives on the wine tourism industry's structural dimensions and wine tourism product. Tourism Management. 24. p. 424- 435.

Charters, S. \& Ali-Kight, J. (2002) Who is the wine tourist. Tourism Management, 23, 311-319.

de Mooij, M. (1998) Global marketing and advertising: Understanding cultural paradoxes. Thousand Oaks, CA: Sage.

Edgar, P. (2014) The changing face of Chinese tourism. [Online] Available from http://www.smh.com.au/small-business/trends/the-changing-face-of-chinesetourism-20140530-399dv.html

Fan, M. (2007) For China's newly affluent, imported wine is de rigueur. [Online] Available from http://www.washingtonpost.com/wpdyn/content/article/2007/01/27/AR2007012701515.html

Gorefield, J. (2015) Europe, Southern. In Martin, S. (Ed.), The SAGE Encyclopedia of Alcohol: Social, Cultural, and Historical Perspectives (pp. 541-544). Thousand Oaks, CA: Sage.

Hojman, D. \& Hunter, J. (2012) Wine tourism: Chilean wine regions and routes. Journal of Business Research. 65 (1). p. 13-21.

Liu, F. \& Murphy, J. (2007) A qualitative study of Chinese wine consumption and 
purchasing: Implications for Australian wines. International Journal of Wine Business Research. 19 (2). p. 98-113.

Marzo-Navarro, M. \& Pedraja-Iglesias, M. (2009) Wine tourism development from the perspective of the potential tourist in Spain. International Journal of Contemporary Hospitality Management. 21 (7). p. 816-835.

Mitchell, R. \& Hall, C. M. (2004) The post-visit consumer behavior of New Zealand winery visitors. Journal of Wine Research. 15 (1), p. 39-49.

Qiu, H.Z., Yuan, J., Ye, H. \& Hung, K. (2012) Wine tourism phenomena in China: An emerging market, International Journal of Contemporary Hospitality Management, 25 (7). p. 1115-1134.

Quackenbush, J. (2015) Napa Valley's Vin65, gliding eagle seek to ease China wine direct-to-consumer shipments. [Online] Available from http://www.northbaybusinessjournal.com/northbay/napacounty/4906226181/easy-china-wine-direct-shipping

Sparks, B. (2007) Planning a wine tourism vacation? Factors that help to predict tourists behavioral intentions. Tourism Management, 28, p. 1180-1192.

Stauss, B. \& Mang, P. (1999) Culture shocks in inter-cultural service encounters. Journal of Services Marketing. 13 (4/5), p. 329-346.

Swindell, B. (2015) Hoping to woo China with white wine. [Online] Available from http://www.pressdemocrat.com/business/3715812-181/hoping-to-woo-chinawith

Yang, Y. and Paladino, A. (2015) The case of wine: understanding Chinese gift-giving behavior. Marketing Letter, 26, p. 335-361.

Yu, Y., Sun, H., Goodman, S., Chen, S. and Ma, H. (2009) Chinese choices: a survey of wine consumers in Beijing. International Journal of Wine Business Research, 21 (2), p. 127-139.

Wine Intelligence. (2013) China wine market landscape report. Wine Intelligence Report, February 2013, London, England.

Keywords: Chinese wine consumer, Wine tourism, Winery tasting room, Winery service quality

Relevance to Marketing Educators, Researchers and Practitioners: This paper helps 
students better understand characteristics of Chinese wine tourists. The paper also illuminates the linkage between winery service quality attributes and Chinese wine tourists' satisfaction and loyalty.

\section{Author Information:}

Kyuho Lee is an Assistant Professor of Marketing at Sonoma State University.

Melih Madanoglu is an Associate Professor of Hospitality Management at Florida Atlantic University.

Jae-Youn Ko is a Professor of Hospitality Management at KyungHee University in Korea.

\section{TRACK: Global Marketing}

